Review

\title{
Tumor-Associated Glycans and Their Role in Gynecological Cancers: Accelerating Translational Research by Novel High- Throughput Approaches
}

\section{Tatiana Pochechueva *, Francis Jacob, Andre Fedier and Viola Heinzelmann-Schwarz}

Gynecological Research Group, Department of Biomedicine, University Hospital Basel, Hebelstrasse 20, 4031 Basel, Switzerland

* Author to whom correspondence should be addressed; E-Mail: tatiana.pochechueva@gmail.com; Tel.: +41612659248.

Received: 31 October 2012; in revised form: 8 November 2012 / Accepted: 9 November 2012 / Published: 14 November 2012

\begin{abstract}
Glycans are important partners in many biological processes, including carcinogenesis. The rapidly developing field of functional glycomics becomes one of the frontiers of biology and biomedicine. Aberrant glycosylation of proteins and lipids occurs commonly during malignant transformation and leads to the expression of specific tumorassociated glycans. The appearance of aberrant glycans on carcinoma cells is typically associated with grade, invasion, metastasis and overall poor prognosis. Cancer-associated carbohydrates are mostly located on the surface of cancer cells and are therefore potential diagnostic biomarkers. Currently, there is increasing interest in cancer-associated aberrant glycosylation, with growing numbers of characteristic cancer targets being detected every day. Breast and ovarian cancer are the most common and lethal malignancies in women, respectively, and potential glycan biomarkers hold promise for early detection and targeted therapies. However, the acceleration of research and comprehensive multi-target investigation of cancer-specific glycans could only be successfully achieved with the help of a combination of novel high-throughput glycomic approaches.
\end{abstract}

Keywords: carbohydrate; malignancy; anti-glycan antibodies; tumor marker; microarray; glycomics; breast cancer; ovarian cancer 


\section{Introduction}

In this review, we provide an overview of well described tumor-associated glycans in gynecological cancers, in particularly ovarian and breast cancers, as the most common and lethal cancers in women, respectively. In addition, we link tumor associated carbohydrates (TAC) to antigenicity and its recognition by the immune system via detection of naturally occurring anti-glycan antibodies. Most of these findings were based on classical studies, such as immunohistochemical staining and ELISA, but with the recent development of glycomic microarray platforms, such as printed glycan array (PGA), glycopeptide array, surface plasmon resonance (SPR) array, suspension array and others, this research has grown rapidly. However, the possible biochemical mechanisms of action of cancer-associated glycans in cancer progression are still under evaluation and are not part of this review, where we will focus more on their occurrence in gynecological cancers and their clinical relevance.

\subsection{Glycans and Cancer}

Glycans (carbohydrates) are poly- or oligosaccharides, homo- or heteropolymers of monosaccharide residues, and important partners in many biological processes including carcinogenesis. Aberrant glycosylation of proteins and lipids occurs commonly during malignant transformation and leads to the expression of tumor-specific glycans [1,2]. The alterations in glycosylation develop very early during carcinogenesis, before any destructive changes in proliferation/apoptosis or cell differentiation become discernible [3]. Tumor-associated carbohydrates (TAC) are expressed by both tumor and host cells and are involved in the key pathophysiological processes during the various steps of tumor progression, including tumor growth, cell migration, invasion, metastasis, angiogenesis, and evasion of innate immunity [4-9]. In past three decades TAC were studied extensively for the use as specific tumor biomarkers and potential therapeutic targets, however, their biological role and functional mechanisms remain still unknown. The classically known TAC are sialyl- Lewis ${ }^{\mathrm{a}}\left(\mathrm{sLe}^{\mathrm{a}}\right.$ ), T (or TF, ThomsenFriedenreich) antigen and Thomsen-nouvelle antigen (Tn), an unsubstituted GalNAc. Basically, TAC can be divided into three major groups: (A) glycosphingolipids of the ganglio- and globo-series; (B) modified lacto-series type 1 (Galß1-3GlcNAc) or type 2 chains (Galß1-4GlcNAc), and (C) core glycan structures of $O$-linked mucin type (T and Tn antigens) [10,11] (Figure 1).

The appearance of aberrant glycan structures, characterized by truncations, increased branching, altered sialylation and/or fucosylation on cancerous cells is typically associated with clinicopathological characteristics such as grade, metastasis and poor prognosis overall. In contrast, some TAC show opposite effects suppressing invasiveness and metastatic potential [2,12]. These aberrantly expressed glycans may reflect alterations of the cognate glycosyltransferase and/or glycosidase network and, initially, dysregulation of the enzyme expression [13,14]. Patterns of glycosyltransferase activities in cancer cell lines indicated that various cancer cells express certain glycan epitopes which could have diagnostic values or serve as treatment targets $[10,15]$. Particularly sialyltransferases and sulfotransferases may play a substantial role in the alteration of glycan performance in cancer cells and have been proposed as prognostic markers in breast cancer patients $[16,17]$. 
Figure 1. The major tumor-associated glycan determinants, reported to be involved in gynaecological cancers. Glycan structures were designed using GlycoWorkbench [18].

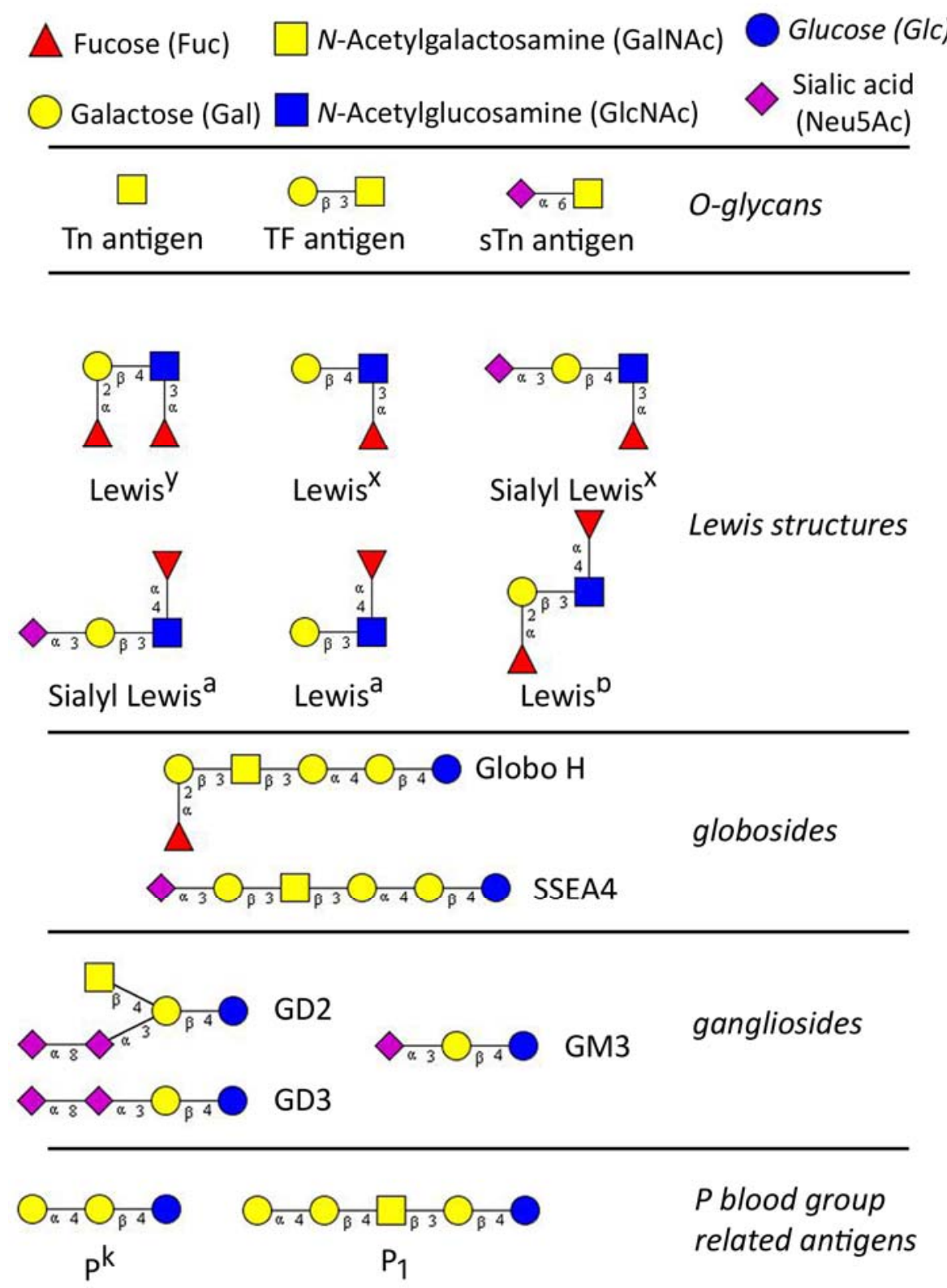

\subsection{Naturally Occurring Anti-Glycan Antibodies}

Anti-glycan antibodies have been shown to be disease-specific, for instance in Crohn's disease [19,20], rheumatoid arthritis [21], infections [22] and cancer [23-25]. These potential anti-glycan antibodies hold therefore promise for disease-specific biomarkers and tumor markers for early cancer diagnostics. Moreover, antibodies against several tumor-associated carbohydrate antigens (TACA) have consistently been observed in human sera [26-28]. Autoantibodies against TACA presumably develop early in carcinogenesis when TACA appear in pre-malignant and malignant lesions. With the help of sensitive novel high-throughput platforms, such as glycopeptide arrays, anti-TACA antibodies 
can be detected in sera long before the antigen [23], and could provide a screening tool for early detection and prognostic assessment.

Unfortunately, only a limited number of human anti-TACA antibodies have been evaluated for their significance in carcinogenesis. For example, an extensive study performed in patients with gastric, colon, rectal and breast cancer revealed that anti-TACA antibodies of IgM subclass against five known cancer antigens bind to carbohydrates on tumor-specific receptors and contribute to apoptosis, possibly playing an immuno-surveillance role [29]. In another study, naturally occurring antibodies against certain gangliosides and glycosphingolipids have been correlated with improved survival in melanoma and were suggested for carbohydrate vaccine design [30]. Today, the new era of glycomics using microarray-based platforms allow the first insight into yet unknown interactions of glycans and naturally occurring anti-glycan antibodies.

\subsection{High-Throughput Technologies to Map Glycan-Antibody Interactions}

Similar to protein research, the standard for investigations into anti-glycan antibodies is both custom-made [26,27,31-35] and commercial ELISA [36-39]. Glycans are usually bound to a carrier (BSA, polyacrylamide), forming glycoconjugates, which are attached non-covalently to a microplate surface. Despite cost-effectiveness the major disadvantage of conventional ELISA is low throughput. Based on former research technologies in transcriptomics and proteomics, glycan microarrays are now new and promising tools allowing the simultaneous detection of glycan-protein interactions. Based on this technology, we have gained insight into endogenous biological processes, microbe-host interactions, and immune defense mechanisms.

Since the introduction of the first glycan-based arrays [40,41] the number of platform variations have continuously increased (summarized in Table 1). The glycan-based arrays are usually incorporating a glycan library which could be constructed from chemically/enzymatically synthesized or natural glycans. Glycan arrays are typically characterized by the fabrication where glycans are covalently attached via a reactive group such as amine [19,40,41], linked to a chemical spacer. Attempts have been made to avoid the use of a linker by covalently- and site-specifically immobilizing carbohydrates onto hydrazine-coated glass slides [42]. This type of platform maps glycan-protein interactions in a monomeric form. Such platforms vary in ligand presentation, density, glycan origin, assay conditions, and immobilization on flat surfaces. All this may influence glycan recognition processes. The possible limitations of glycan arrays might be a restricted flexibility in terms of assay reconfiguration and monomeric presentation of glycans on the array. 
Table 1. Characteristics of major glycan-based array platforms.

\begin{tabular}{|c|c|c|c|c|c|c|}
\hline Array type & Ref. & $\begin{array}{c}\text { Glycan- } \\
\text { presentation }\end{array}$ & $\begin{array}{c}\text { Assay } \\
\text { dynamics }\end{array}$ & $\begin{array}{l}\text { Immobilization } \\
\text { (theoretically) }\end{array}$ & $\begin{array}{l}\text { Serum } \\
\text { dilution }\end{array}$ & detection \\
\hline $\begin{array}{c}\text { ELISA } \\
\text { (Glycominds) }\end{array}$ & {$[36-39,43-45]$} & $\mathrm{n} / \mathrm{a}$ & Static & $n / a$ & 1:101 & $\begin{array}{l}\text { Anti-human IgA, IgG or IgM separately } \\
\text { and each HRPO conjugated }\end{array}$ \\
\hline ELISA & {$[26,27,31,33-35]$} & polymeric & Static & $\begin{array}{l}\text { Non-covalent and } \\
\text { non site-specific }\end{array}$ & $\begin{array}{l}1: 25 \text { (up } \\
\text { to } 1250\end{array}$ & $\begin{array}{l}\text { Anti-human Ig (IgA+IgG+IgM), IgG and } \\
\text { IgM HRPO conjugated, IgM and IgG both } \\
\text { AP conjugated; }\end{array}$ \\
\hline ELISA & [32] & polymeric & Static & $\mathrm{n} / \mathrm{a}$ & $\begin{array}{l}\text { Undiluted } \\
\text { up to } \\
1: 10000\end{array}$ & $\begin{array}{l}\text { Anti-human IgD, IgG2 and IgM and anti- } \\
\text { mouse IgG HRPO conjugated }\end{array}$ \\
\hline SPR array & [46] & $\begin{array}{c}\text { Monomeric/p } \\
\text { olymeric }\end{array}$ & Flow & $\begin{array}{l}\text { Covalent and site- } \\
\text { specific }\end{array}$ & 1:50 & Anti-human IgG or IgM \\
\hline $\begin{array}{l}\text { Suspension } \\
\text { array }\end{array}$ & {$[47,48]$} & polymeric & Flow & $\begin{array}{l}\text { Covalent and site- } \\
\text { specific }\end{array}$ & 1:40 & $\begin{array}{l}\text { Anti-human IgM or IgG R-phycoerythrin } \\
\text { conjugated }\end{array}$ \\
\hline Glycan array & {$[24,49-52]$} & monomeric & Static & $\begin{array}{l}\text { Covalent and site- } \\
\text { specific }\end{array}$ & 1:15 & $\begin{array}{l}\text { Anti-human IgA, IgG\&IgM biotin } \\
\text { conjugated; Streptavidin-Alex }{ }^{555} \\
\text { conjugated }\end{array}$ \\
\hline Glycan array & {$[53,54]$} & monomeric & Static & $\begin{array}{l}\text { Covalent and site- } \\
\text { specific }\end{array}$ & $1: 20$ & Cy3 conjugated anti-human IgG or IgM \\
\hline Glycan array & {$[19,41,55,56]$} & monomeric & Static & $\begin{array}{l}\text { Covalent and site- } \\
\text { specific }\end{array}$ & $\begin{array}{l}1: 20 \text { (up } \\
\text { to } 1: 40 \text { ) }\end{array}$ & $\begin{array}{l}\text { Anti-human IgA,IgG\&IgM or separately } \\
\text { all of them biotin conjugated; } \\
\text { Streptavidin-europium conjugated }\end{array}$ \\
\hline Glycan array & [57] & monomeric & Static & $\begin{array}{l}\text { Covalent and site- } \\
\text { specific }\end{array}$ & 1:100 & Cy3 conjugated anti-human IgG \\
\hline $\begin{array}{l}\text { Glycopeptide } \\
\text { array }\end{array}$ & [58-62] & polymeric & Static & $\begin{array}{l}\text { Covalent and } \\
\text { (semi-) site } \\
\text { specific }\end{array}$ & 1:50 & $\begin{array}{l}\text { Cy3 conjugated anti-human IgG, IgM, IgA } \\
\text { together and separately }\end{array}$ \\
\hline $\begin{array}{l}\text { Glycopeptide } \\
\text { array }\end{array}$ & {$[23,25,63]$} & polymeric & Static & $\begin{array}{l}\text { Covalent and site- } \\
\text { specific }\end{array}$ & $\begin{array}{l}1: 25 \text { (up } \\
\text { to } 1: 3000 \text { ) }\end{array}$ & $\begin{array}{l}\text { Cy3 conjugated anti-human IgG, IgA and } \\
\text { IgM separately (in combination and study } \\
\text { dependent) }\end{array}$ \\
\hline
\end{tabular}

More recently, new high-throughput platforms have been introduced which are referred to as glycopeptide arrays (Table 1). This array format is characterized by the addition of a carrier protein or polypeptide forming glycoconjugate-based epitopes. Profiling anti-glycan antibodies to glycopeptides on array platforms has been reported for instance by applying bovine serum albumin as carrier protein to epoxide-derivatized slides [61]. In this study neoglycoconjugates were fabricated and carbohydrates synthesized to investigate the antigenicity to anti-glycan antibodies. Another platform utilizes an identified cancer-specific immunodominant glycopeptide epitope in MUC1 [64], a heavily glycosylated mucin known to be associated to several cancer types including breast and ovarian cancer. A synthesized MUC1 peptide was also used as a carrier for the chemoenzymatic synthesis of glycoconjugates ( $O$-glycopeptides), on $N H S$-activated glass slides via amine group guaranteeing covalent and site-specific attachment $[23,25,63]$. Glycan and glycopeptide arrays are optimal glycanbased immunoassays to profile anti-glycan antibodies in high-throughput but concerns still remain 
because assay dynamics are static, background binding is controversial, and detection of bound antiglycan antibodies can only be visualized by the use of chemical labels and multiple-step procedures. In parallel to glycan-based arrays, microarray technologies using immobilised lectins for glycomic analysis emerged in the past decade (for review see [65]), but they are beyond the scope of this review.

New technologies in the field of glycan-based immunoassays were introduced which may overcome the previously mentioned limitations. These are glycan-based suspension arrays as well as surface plasmon resonance (SPR) platforms (Table 1). Both technologies are characterized by flow assay dynamics narrowing glycan-antibody interactions more closely to an in vivo environment. Recent advances in the field of flow-cytometry enabled a new generation of microbead-based immunoassays, allowing for quantitative simultaneous detection of multiple analytes in a single sample with high sensitivity and reproducibility (for review see [66]). We have utilized this technology to create the first glycan-based suspension array for human anti-glycan antibody profiling [67]. The innovation of this approach is the combination of unique chemically synthesized monobiotinylated glycopolymers [68] used for microbead modifications with the advantages of multiplexed flow-cytometric detection. Optically-encoded microbead-based arrays are characterized by increased control over array preparation, easy reconfiguration of arrays and stability of pre-coated microbeads [69]. Since glycanbased arrays are ideal for screening of very broad glycan libraries, glycan-based suspension array seems to be optimally suited for simultaneous detection of up to several dozens of analytes, thus holds a great diagnostic potential for human serum antibodies in a clinical setting.

Biophysical sensing techniques based on evanescent waves such as SPR have matured to become major tools in protein expression analysis and have also gained considerable momentum in the pharmaceutical industry. Glycan array based on SPR technique allows real-time and label-free detection of carbohydrate-protein binding and to expand the picture of monomeric antigenicity (as in glycan-based microarrays) to a polymeric presentation of glycans. SPR-based measurements are currently possible in a mid- to high-throughput format. As an example, de Boer and co-workers have utilized a SPR array platform which contained 144 glycan structures, released from their natural source [46]. Glycans were covalently and site-specifically attached to epoxide modified surface via fluorescence spacer contained amine group. The chip represented the glycan repertoire of the human parasite Schistosoma mansoni. Anti-glycan antibodies of IgG and IgM subclass were recognized in infected and non-infected human serum samples, demonstrating an effective set up of SPR-based screening of anti-glycan antibodies. Another SPR-based glycan assay, composed of a limited number of mannose and galactose derivatives, was constructed showing its feasibility mapping glycan-protein interactions with known lectins (PNA, soybean agglutinin and others) [70].

\section{TAC in Gynecological Cancers}

\subsection{Tn Antigen}

The Tn ( $N$-acetylgalactosamine; GalNAc $\alpha$-O-Ser/Thr, Figure 1) antigen refers to a monosaccharide which is usually attached to the amino acids serine or threonine (or tyrosine in a few cases) of a peptide by a glycosidic bond (forming $O$-glycan). Tn is a cryptic precursor of the $\mathrm{T}$ antigen (Core 1) and can be unmasked if cells lose their ability to synthesize Core 1 structure. The expression of Tn was 
first discovered in 1957 on subpopulations of blood cells characterizing a rare hematological disorder, the Tn syndrome [71]. In the classical work of Springer it was shown that Tn as the truncated form of oligosaccharide chains are abundantly expressed on carcinoma cells [28]. These simple TACA can be carried by cancer-associated mucins and occur in around $90 \%$ of breast carcinomas, but are masked in benign and healthy tissues [28,72-76]. Assays based on monoclonal antibodies (mAb) and lectins have shown that expression of $\mathrm{Tn}$ in breast cancer is associated with high grade ductal carcinomas $[3,75,77]$. Its expression was found to significantly predict a shortened 5-year disease free survival, a positive lymph node status and increased combined histological stages [75]. Another study found that Tn antigen expression detected by Tn-specific Vicia villosa lectin (VVL-B 4 ) in ovarian cancer was correlated with increased malignancy, metastatic progress and low patient survival [2]. Increased Tn antigen expression is also correlated with metastatic potential and poor prognosis in cervical cancers $[78,79]$.

Nevertheless, the mechanisms linking Tn antigen expression to cancer progression still remain unknown. Tn on MUC1 was shown to be bound by the macrophage galactose-type lectin on macrophages and dendritic cells [80] and Tn presence may enable the tumor to escape immunosurveilance [81]. Beside its aberrant function the genetic basis causing Tn appearance on $O$ glycoslyated proteins is still under investigation. It is becoming evident that the loss of functional COSMC is one molecular explanation for the increased Tn expression on human cancer cells [82]. COSMC is an essential chaperone for correct protein $O$-glycosylation and loss of COSMC is associated with loss of T-synthetase and increase in Tn antigen [83]. In cervical cancer a deletion of functional allele ( $\mathrm{LOH})$ leads to complete absence of COSMC and increased expression of Tn and sTn [82].

Early pioneering work by Springer and colleagues reported experiments for long-term anticarcinoma vaccination and treatment of breast cancer [84] without delivering additional proof. Tn expression has been linked to tumor progression and targeted cancer treatment which has been used for anti-cancer vaccination and treatment of breast cancer [64]. Carbohydrates alone do generally not activate $\mathrm{T}$ lymphocytes and have therefore reduced immunogenicity [85]. The increased immunogenicity can be achieved by linking Tn to carrier protein such as keyhole limpet haemocyanin (KLH) [86], MUC1 peptide [87,88], or the use of immunological adjuvants such as saponin [89], forming glycoconjugates to generate anti-glycan antibodies. A pilot study in a cohort of epithelial ovarian, fallopian tube, and peritoneal cancer showed an induced prevalently IgM-antibody response to a heptavalent vaccine including Tn and Tn-MUC1. Only Tn-MUC1 revealed both IgM and IgG response [90]. These observations are in concordance with another more recent study where natural anti-glycan antibodies were detected using a glycopeptide array [25]. This clearly indicates recognition of Tn by the cognate immune system. Despite the chemical simplicity of Tn antigen, its antigenetic structure is considered to be rather complex and recent data suggest that Tn antigen antibody binding capacity is determined by the peptide context of Tn antigen [91]. This finding is of importance due to previously used Tn-peptide vaccines and should therefore be considered. In addition, first promising clinical trials in prostate cancer patients showed that only cancer-specific Tn expression on tumor cell surface enables targeting and site-specific treatment [86]. 


\subsection{Sialyl-Tn Antigen}

STn antigen tissue expression and its presence in blood were found in various gynecological cancers originating from the ovary, cervix, endometrium and vulva. The transfer of sialic acid in $\alpha 2,6-$ linkage to Tn structure usually terminates the further elongation of oligosaccharide. Therefore, sialylTn (sTn, Neu5Aca2-6GalNAca-O-Ser/Thr, Figure 1) expression leads to a shortening of $O$-glycan chains [2]. STn displays restricted expression in normal tissues [72,92], but can be detected at various frequencies in almost all kinds of carcinomas, even more frequently in adenocarcinomas. At least 25$30 \%$ of breast cancers are sTn-positive [93] and overexpression of sTn occurs in almost $40 \%$ of breast cancers [94]. STn expression was found to be higher in ovarian cancer patients which were associated with shorter survival [95]. There is increasing evidence that sTn expression is similarly associated with survival in breast cancer [96-99], potentially as a short-term outcome [97]. In node-positive breast cancer patients sTn expression was also correlated with a lack of response to adjuvant chemotherapy [98]. Using immunohistochemical staining and anti-sTn monoclonal antibody (TKH-2), the disaccharide was detected in a majority of ovarian and cervical cancers with no positive match in remaining cancer types, benign, and normal controls [79]. A reduced number of tissue sTn positive samples also showed detectable levels of serum sTn. Using the same mAb directed to sTn, another study found detectable levels of sTn in serum of ovarian cancer patients which significantly correlated with increased malignancy, metastatic progression and low patient survival [100]. An increased sTn expression in ovarian carcinoma cells was detected when primary tumors were compared with metastatic lesions [101]. Another study of the same investigators, conducted on tissue samples from 45 patients, confirmed that sTn is widely expressed in ovarian carcinomas and related metastases, but could not verify sTn expression to be predictable of disease outcome [102]. There is a clear indication that sTn expression in tissue and blood serum correlates with tumor progression in breast and ovarian cancer. The mechanisms, underlying the appearance of this $O$-glycan in several types of carcinomas is still unknown, as is its varied tissue expression. One possible explanation suggests an increased gene expression of ST6GalNAc-I glycosyltransferase, the enzyme which transfers sialic acid to Tn antigen, thus creating Neu5Aca2-6GalNAc, which is the sTn epitope [103]. It has been demonstrated that this is not the case in colon cancer because ST6GalNAc-I activity was not elevated in cancerous colonic tissues as compared to normal mucosa. In contrast, sTn was detected in cancer cells and was absent in normal controls [104]. The transfection of ST6GalNAc-I and reconstitution of sTn expression was performed in breast cancer cells and demonstrated that the expression of RNA-encoding ST6GalNAc-I and the expression of sTn are directly linked [93]. The discrepancy to observations in colon cancer were explained by reduced sialic acid $O$-acetylation, unmasking sTn for mAb recognition [105]. STn antigen is usually present on $O$-glycosylated proteins such as MUC1 [106], CD44 [107], and MUC16 [108]. It has been suggested, that altered glycosylation of these molecules may influence adhesion and migration (motility) of cancer cells. Namely, sTn expression in breast cancer cells is sufficient to modify biological features, decreasing adhesion and increasing migration and tumor growth $[109,110]$. CD44 as the main hyaloronan (nonsulfated glycosaminoglycan) receptor appears to play an important role in mediating the binding of tumors to the extra-cellular matrix (ECM) [111,112]. STn as a classical TACA has also been demonstrated to be widely recognized by naturally occurring antibodies 
not only in cancer patients, but in healthy controls. In a study on 106 healthy donors which investigated the binding to anti-glycan antibodies on a glycan array, high-levels of anti-sTn antibodies were found [52]. In a study of ours, using the same glycan array, we also observed detectable levels of anti-glycan antibodies to sTn in healthy and non-mucinous ovarian cancer patients without significantly distinguishing these two groups [24]. In addition, our custom-made suspension array $[48,67]$ detected anti-sTn antibodies that significantly correlated with clinico-pathological characteristics of gynecologically investigated samples (data not published). Glycopeptide array incorporating sTn-MUC1 $1_{60 \text { mer }}$ glycopeptides revealed high levels of anti-sTn antibodies significantly associated with reduced incidence and increased time to metastasis in breast cancer patients [23]. In so far as elevated levels of sTn in breast cancer are associated with poor prognosis, these findings on antisTn antibodies suggest their evident role in anti-cancer immune response. Nevertheless, a direct proof showing correlation of anti-sTn antibody levels in patient sera and sTn expression in matched tissue samples is still needed.

\subsection{T Antigen}

Another $O$-linked disaccharide with a potential tumor association is T antigen (Gal $\beta 1$-3GalNAc $\alpha$ $\mathrm{O}-\mathrm{Ser} / \mathrm{Thr}, \mathrm{T}$, Figure 1) also referred to as Thomsen-Friedenreich antigen (TF) or Core 1 glycan. T antigen, initially described on glycophorins on red blood cells, is the cryptic precursor of Core $2 \mathrm{O}$ glycans, which can be unmasked if cancer cells lose their ability to synthesize Core 2. Namely, T antigen is unsialylated Core 1.

It is known that TF occurs in $\sim 90 \%$ of all human cancer cells including precancerous conditions [113]. Springer and co-workers first showed immunohistochemically (using peanut lectin (PNA) and natural human anti-T antibodies), that breast cancers, but not benign tumors or normal mammary cells, expressed $\mathrm{T}$ antigen [114,115]. Their further investigations, conducted on primary invasive breast ductal cancer tissues using mAbs and lectins, demonstrated, that $\mathrm{T}$ epitope expression showed no statistically significant association with prognostic factors [75,116]. Also, no prognostic value of $\mathrm{T}$ antigen in breast carcinomas was detected by PNA staining [117]. With the use of T-specific mAbs, however, a worse prognostic impact of T-expression in breast cancers was found [118]. In contrast, another study [119] using mAbs showed the correlation of $\mathrm{T}$ antigen expression in breast cancer with a better prognosis, which was opposite to gastrointestinal, lung or cervical cancers. A recent study demonstrated immunohistochemically that $\mathrm{T}$ antigen was significantly expressed in normal epithelium compared to CIN I, CIN II and invasive cervical cancer [120]. These contradictory results may be related to technical and experimental limitations and use of different probes [121,122]. Also, small haptens (as disaccharide $\mathrm{T}$ ) are differently recognized by antibodies in natural microenvironment (being numerously attached to protein backbone) and in immunoassays (ELISA, PGA) [49,123]. In ovarian cancer $\mathrm{T}$ antigen specific expression was described depending on the ovarian cancer histotype $[95,124,125]$.

There are several indications that TF is expressed in cancerous cells and therefore refers to TACAs. Nevertheless, only recent studies have started to investigate its molecular function. There are some indications that TF antigen may play a role in oncogenic proliferation [86,116]. No certain mechanism of TF antigen action has been described, on the other hand, although TF could be a good ligand to 
galectin 3 [126,127], which has been reported to promote breast cancer metastasis by adhesion to endothelial cells. TF binding abilities of galectin 1 and 3 were recently investigated using crystallization studies and SPR assay demonstrated increased affinity of galectin 3 over galectin 1, identifying a unique motif for TF binding [128]. The results additionally indicate that TF could be recognized by galectins, a family of beta-galactoside binding proteins involved in modulation of cellcell and cell-matrix interactions.

The cancer-specific association of TF shows that this glycan would probably have clinical applications. For instance, application of anti-TF mAb successfully inhibited lung metastasis in mice and improved prognosis in a mouse breast cancer model [129]. In a vaccination study using TF conjugated to KLH in combination with an adjuvant therapy in ovarian cancer, a clear immune recognition of TF-glycoconjugates were found with anti-glycan antibody responses of $\operatorname{IgM}(n=9), \operatorname{IgG}$ and also IgA subclasses [130]. The immune response was also observed in a more recent study in prostate cancer patients [86].

\subsection{Lewis Structures}

Lewis structures are blood group antigens which contain fucose. This monosaccharide is either $\alpha 1-3$ or a1-4 linked to $N$-acetylglucosamine (GlcNAc). The histo-blood group Lewis antigens are found in most human epithelial tissues, as far as they are terminal parts of glycolipids and glycoproteins. There are two types of Lewis glycans: (A) $\mathrm{Le}^{\mathrm{a}}, \mathrm{sLe}^{\mathrm{a}}$ and $\mathrm{Le}^{\mathrm{b}}$, all derived from type 1 structures (Gal $\beta 1$ $3 \mathrm{GlcNAc}, \mathrm{Le}^{\mathrm{c}}$ ) and their positional isomers (B) $\mathrm{Le}^{\mathrm{x}}, \mathrm{sLe}^{\mathrm{x}}$ and $\mathrm{Le}^{\mathrm{y}}$, derived from type 2 chains (Gal $\beta 1$ 4GlcNAc) with substitutions by fucose and sialic acid (Figure 1).

In healthy individuals, $\mathrm{Le}^{\mathrm{a}}$ and $\mathrm{Le}^{\mathrm{b}}$ (type 1) as well as $\mathrm{Le}^{\mathrm{x}}, \mathrm{Le}^{\mathrm{y}}$, sialyl-Le ${ }^{\mathrm{x}}$, sulfo-Le ${ }^{\mathrm{x}}$ (type 2)- Lewis antigens are normally expressed as terminations of numerous glycoconjugates and are characterized by an overall lack of autoantibodies [52]. However, Lewis structures have been widely reported to be associated with cancerous conditions. In general, reduced expression of type 1 Lewis antigens and increased expression of type 2 antigens have been observed more or less consistently in carcinogenesis $[131,132]$. Loss of $\mathrm{Le}^{\mathrm{b}}$ and, to some extent $\mathrm{Le}^{\mathrm{a}}$, in invasive ductal carcinomas of the breast compared to normal and benign tissues was correlated with the grade of malignancy $[133,134]$. Expression of sLe $^{\mathrm{x}}$ (type 2 structure) on the other hand, was increased in patients with advanced and recurrent breast cancer $[135,136]$.

Breast cancer and $80 \%$ of ovarian cancers are of epithelial origin and the most characteristic TACAs in these cancers are sialylLe ${ }^{\mathrm{x}}\left(\mathrm{sLe}^{\mathrm{x}}\right)$, sialylLe ${ }^{\mathrm{a}}\left(\mathrm{sLe}^{\mathrm{a}}\right)$, and $\mathrm{Le}^{\mathrm{y}}$, occurring in most human epithelial tissues $[99,131,132,137,138]$. In cancer, overexpression of $\mathrm{sLe}^{\mathrm{x}}$ or $\mathrm{sLe}^{\mathrm{a}}$ antigens and the general increase in sialylation are typical alterations $[139,140]$. When found at the surface of carcinoma cells, they are usually associated with a poor prognosis in tumors of certain type, stage and grade, and reduced overall survival [98,139]. The expression of $\mathrm{sLe}^{\mathrm{x}}$ in breast cancers is also considered to be an independent prognostic indicator of survival regardless of the primary tumor and lymph node involvement [141]. Elevated $\mathrm{sLe}^{\mathrm{x}}$ expression was found in patients with metastases compared to those without [136], and $\mathrm{sLe}^{\mathrm{x}}$ was increased in serum of patients with advanced breast cancer $[135,136]$. Combined detection of CA15-3, the most commonly used breast cancer tumor marker, and $\mathrm{sLe}^{\mathrm{x}}$ in serum improved the effectiveness of monitoring metastatic breast cancers $(78.5 \%$ 
versus 61.5\%, when measured by CA15-3 alone) [142]. Using high-performance liquid chromatography (HPLC) and mass-spectrometry (MS) a number of $\mathrm{sLe}^{\mathrm{x}}$ bearing proteins were identified as predictors of breast cancer progression in patients with advanced breast cancer [135]. The $\mathrm{N}$-glycan profiles from healthy and advanced breast cancer groups were significantly altered, as highlighted by an average 2-fold increase of $\mathrm{sLe}^{\mathrm{x}}$ in the serum of cancer patients. This preliminary finding indicates that elevated levels of this potential glycan marker might be a better marker than CA 15-3. Controversially, an immunohistochemical evaluation of a cohort of 127 patients with primary breast cancer of various stages and grades has demonstrated, that $\mathrm{sLe}^{\mathrm{x}}$ expression was not correlated with prognosis and survival [143]. Studies conducted on primary ovarian carcinomas and metastatic lesions, demonstrated that $\mathrm{Le}^{\mathrm{y}}$ and $\mathrm{sLe}^{\mathrm{x}}$ are widely expressed in both, but their expression did not seem to correlate with long- or short-term survival [101,102]. The characteristic changes in total serum $N$-glycans from patients with advanced ovarian cancer of different type, were examined by HPLC, weak anion exchange HPLC and MS [144]. These changes included increases in levels of core fucosylated, agalactosyl biantennary glycans, presented on IgG heavy chains, and in levels of sLe ${ }^{\mathrm{x}}$, linked to acute-phase proteins, such as haptoglobin, $\alpha 1$-acid glycoprotein, and $\alpha 1$-antichymotrypsin.

The mechanisms defining $s L e^{x}$ and $s L e^{a}$ malignancy are more explained than in other TAC. SLe ${ }^{\mathrm{x}}$ and sLe ${ }^{\mathrm{a}}$ are known ligands for E-selectin $[99,100]$ and are known to facilitate cancer cell metastasis, mediating their extravasations from blood to peripheral tissues via E-selectin, expressed on vascular endothelium [145-150]. Some of these investigations were conducted on the breast cancer model and were supported by clinicopathological data $[131,146]$. Thus, both $\operatorname{sLe}^{\mathrm{x}}$ and soluble E-selectin were significantly elevated in the serum of breast cancer patients with advanced and recurrent disease [151]. Both P- and E-selectin expression was significantly elevated on endothelial cells of breast cancer patients [152]. The recent study confirmed E-selectin- driven mechanism of $\mathrm{sLe}^{\mathrm{x}}$ action in carcinogenesis [153]. Importantly, the authors demonstrated that glycosylation profiles differ between estrogen receptor (ER)-positive and ER-negative breast cancers with higher incidence of $\mathrm{sLe}^{\mathrm{x}}$ in ERnegative breast tumors due to significantly elevated expression of corresponding glyco-genes. SLe ${ }^{\mathrm{x}}$ expression had no influence on the survival of patients regardless of their ER-positive or ER-negative status. However, high expression of $\mathrm{sLe}^{\mathrm{x}}$ in ER-positive tumors correlated with bone metastasis - the expression site of E-selectin, the receptor for $\mathrm{sLe}^{\mathrm{x}}$. The authors suggest that selectins may promote metastasis in breast cancer through protein-associated $\operatorname{sLe}^{\mathrm{x}}$ and heparansulfate (HS) glycosaminoglycans, as their expression was similarly increased in ER-negative tumors and they may engage with selectins (L/P-selectin) via various microdomains [154]. Notably, selectin affinity depends strongly on $\mathrm{sLe}^{\mathrm{x}}$ microenvironment: for example, E-selectin weakly binds to $\mathrm{sLe}^{\mathrm{x}}$-containing glycolipids [155], but has a strong affinity for $O$-glycan associated $\mathrm{sLe}^{\mathrm{x}}$, expressed by neutrophils [156].

$\mathrm{Le}^{\mathrm{y}}$ (difucosylated Lewis antigen type 2) is overexpressed in 60 to $90 \%$ of cancers of epithelial origin, including breast and ovarian cancer [157] and correlated in lymph node-negative breast cancers with poor prognosis and decreased patient survival [158]. Le ${ }^{\mathrm{y}}$, being overexpressed in $75 \%$ of ovarian carcinomas, correlated with highly malignant phenotype[159]. These findings indicate the impact of fucosylation in carcinogenesis. $\mathrm{Le}^{\mathrm{y}} / \mathrm{Le}^{\mathrm{b}}$ - induced drug resistance in ovarian cancer cell lines has been reported [160]. Overexpression of $\mathrm{Le}^{\mathrm{y}}$ presumably confers cell adhesion-mediated drug-resistance to apoptosis in ovarian cancer cells by up-regulation of TOPO I and TOPO II $\beta$ proteins [161]. Le ${ }^{\mathrm{y}}$ 
structures were found to be associated with CD44, and it was shown that overexpressed $\mathrm{Le}^{\mathrm{y}}$ strengthens CD44 mediated adhesion and spreading of ovarian cancer cells [162].

\subsection{Glycoshingolipids}

\subsubsection{Gangliosides}

Glycosphingolipids are glycolipids containing the amino alcohol sphingosine. Gangliosides, as one out of three subgroups of glycosphingolipids, are ubiquitous membrane-associated glycolipids containing one or more neuraminic acids. Gangliosides are derived from lactosylceramide and additional glycan residues - Neu5Ac, GalNAc and Gal (Figure 1). There are a-, b- and c-series of gangliosides synthesized by sequential activities of sialyltransferases and glycosyltransferases. In adults, they are normally thought to be restricted to the central nervous system [163] but gangliosides seem to also play important roles in breast cancer progression and metastasis [164,165]. A prominent candidate is the disialoganglioside GD2 (Figure 1). A very recent study identified ganglioside GD2 as potential breast cancer stem cell marker and demonstrated its involvement in carcinogenesis. These cells bearing GD2 were capable of forming mammospheres and initiating tumors. In addition, gene expression analysis revealed that GD3 synthase gene expression is responsible for the presence of GD2 [166]. Gangliosides GM3, GD3 (Figure 1), as well as unusual $O$-acetylated gangliosides (9-O-acetylGD3, 9-O-acetyl-GT3), were found to be overexpressed in about $50 \%$ of breast cancer patients [167]. Another ganglioside, $\mathrm{N}$-glycolyl-GM3, not found in normal human tissues, was detected in primary tumors of FIGO Stage II breast cancer [167,168]. Overexpression of monosialoganglioside GM3 and disialoganglioside GD3 (Figure 1) may correlate with higher malignancy of breast cancer cells by enhancing cell proliferation and migration [165]. Total levels of gangliosides were also observed to be increased in serum and ascites of patients with advanced ovarian cancer [169], indicating the process of shedding or release of gangliosides, which is associated with cancer progression. It was suggested, that shedding of gangliosides into the local tumor microenvironment contributes to tumor strategies to evade immune recognition, thus high concentration of circulating gangliosides is associated with poor prognosis. The mechanism of evasion of the innate immune response may be based on inhibition of antitumor natural killer T (NKT) cell response. Such action of circulating ganglioside GD3, purified from ovarian cancer-associated ascites was recently shown by Webb and co-workers [170].

\subsubsection{Globosides}

Globo $\mathrm{H}$ and stage-specific embryonic antigen 4 (SSEA 4) have the same precursor, stage-specific embryonic antigen 3 (SSEA3), and therefore sharing a structural motif (Figure 1). Both glycosphingolipids, Globo $\mathrm{H}$ and SSEA4, are only different by their terminating monosaccharide, $\alpha 1-$ 2-linked Fucose and $\alpha 2-3$-linked Neu5Ac, respectively (Figure 1). These glycans are of importance because both have been described in association with cancer.

Globo H, a fucosylgalactosylgloboside, was originally characterized by Hakomori and co-workers in a human breast cancer cell line [171]. Expression of Globo H (both as GSL and glycoprotein) in 143 cases of breast cancer was not correlated with patient survival [172]. Using glycan array a significant difference in anti- Globo $\mathrm{H}$ antibody levels in serum of breast cancer patients and healthy donors was 
demonstrated, and the increase of Globo $\mathrm{H}$ in breast cancer stem cells was associated with the disease progression [53]. Globo $\mathrm{H}$ was also found to be expressed in ovarian cancer [2,173].

\section{Conclusions and Discussion}

Despite immense progress in research of cancer-associated glycans during the past three decades, this area of glycobiology and molecular oncology still opens broad possibilities for scientific discoveries. A number of regularities of cancer-associated glycosylation were clearly defined. We have mentioned and discussed the main known cancer-associated glycans involved in breast and ovarian cancer. For example, breast cancer cells express truncated Core 1-based glycans including T, Tn and sTn antigens instead of elongated $O$-chains. The expression of sialyl-Lewis antigens is also altered and complex gangliosides are overexpressed in invasive ductal carcinomas. In ovarian cancer, $\mathrm{sLe}^{\mathrm{x}} / \mathrm{sLe}^{\mathrm{a}}$ and their analogues as well as sTn and $\mathrm{Le}^{\mathrm{y}}$ have been correlated with metastatic potential and patient survival. However, lectins and most monoclonal antibodies, used in classical studies, are not strictly specific for certain carbohydrate structures but expose some degree of cross-reactivity (for review see [121]). Thus, novel glycan cancer associated epitopes, especially combined glyco-peptide and -lipid epitopes, presumably specific for certain cancer types/stages/grades are still in the process of identification. We need to know more about TACA, the structure of TACA-bearing glycoconjugates, the role of their molecular architecture in vivo for immune recognition, alterations of glycosyltransferase expression in cancer, and, finally, the molecular mechanisms of their action. Currently, the mechanisms defining malignancy are fairly understood only for $\mathrm{sLe}^{\mathrm{x}}$ and $\mathrm{sLe}^{\mathrm{a}}$, as these TACA mediate binding of tumor cells to microvascular endothelium through E-selectin expressed on the endothelial cells. The biochemical mechanisms of action of other cancer-associated glycans in cancer progression are still under evaluation $[5,9,11]$.

Naturally occurring anti-glycan antibodies have been demonstrated to recognize TACA in many different types of malignant diseases as observed through glycan-antibody interaction. In the past decade, high-throughput glycan arrays as well as glycopeptide arrays have been increasingly used. These approaches already contribute to biomarker research in breast and ovarian cancer, and will be powerful tools in the future, when increasing efficiency, sensitivity and preciseness will allow cancer diagnostics and therapeutics of high-sensitivity.

Despite detected TACA-specific interactions with antibodies, it is crucial to conclude that TACA are specifically expressed or shed by cancer cells and the direct proof of their presence is often missing. It is therefore required to test matched serum samples from the same patients using alternative methods. Matched tissue samples of normal and cancer patients can allow the identification of TACA directly. This can easily be achieved by standard immunohistochemistry using mAbs or lectins. The latter are known to bind various glycan structures sharing carbohydrate motifs or epitopes (for review see [174]).

Other possibilities are the identification of glycan structures by MS-based profiling and the analysis of glycan complements in plasma and tissues, which allows for the comprehensive analysis of membrane protein glycosylation. The high-throughput glycan profiling by MS requires only minute volumes of patient serum, thus representing an essentially non-invasive diagnostic method. This highly sensitive method in contrast to glycan-based immunoassays, detecting anti-TACA antibodies (glycan 
and glycoconjugate based platforms), can be used for direct glycomic mapping and as a proof of glycoarray-based findings.

In breast cancer research a sensitive specific MS (MALDI-TOF MS)-based glycomic profile was performed to analyze $\mathrm{N}$-glycans in serum of control as well as early- and late-stage breast cancer patients. Various MS-based technologies in combination with other methods (high performance liquid chromatography, capillary electrophoresis) were also consistently used for the investigation of gynecological cancer associated glycan alterations over the past decade [93,135,144]. Differences in glycomic profiles revealed a substantial increase of fucosylation (both in core structures and the branched segments) in cancer patients, whereas various sialylated structures in serum presented a less clear picture. In one study changes in relative intensities of eight glycans are characteristic of breast cancer, whereas some other glycan structures might contribute additionally to distinctions in the recognizable patterns [175].

For the establishment of potential new tumor markers and understanding the functional role of antiglycan antibodies, validation of glycan-based techniques still remains complex and complicated due to the limited number of samples, the heterogeneous pathology of cancer diseases - especially in epithelial ovarian cancer, the absence of independent glycan-based immunoassays, and the fabrication of glycans itself. We have profiled our previously detected top candidate $\mathrm{P}_{1}$ trisaccharide [24] in an independent cohort using an independent glycan-based immunoassay [48]. We have also utilized ABO blood group antigens, A and B trisaccharides, to study the reproducibility of different glycan-based immunoassays, presentation of glycans, the use of various types of glycoconjugates, and assay dynamics. We found a high correlation of anti-glycan antibody levels in ABO blood group antigens using three methods: ELISA, printed glycan and suspension array. Interestingly, in terms of $\mathrm{P}_{1}$ trisaccharide correlation between methods decreased from moderate to low indicating that presentation of glycan, antigen/ antibody ratio, assay conditions and detection technique is crucial. This further indicates that the glycan-antibody interaction of interest has to guide the assay selection [48].

In conclusion, as can be observed from the literature and from our own research, TAC could be excellent biomarkers for cancer. Also, the immune response in cancers is clearly and predominantly related to the glycan, or combined glycopeptide/glycolipid epitopes - whether expressed as glycoproteins or glycolipids. Recent advances in glycomics enabled development of novel highthroughput experimental and technical platforms for TAC research, which was classically based on immunohistochemical studies. These analyses of simple TACA unraveled the main features of aberrant cancer-associated glycosylation, but could not reveal the entire information concerning specific and complex modifications in total glycoconjugates during carcinogenesis. Nowadays there are various platforms available profiling human anti-glycan antibodies to identify potential glycan-antibody interactions. These novel approaches include printed glycan array, glycopeptide arrays, bead-based suspension array, and SPR array. These platforms show great potential as usable and powerful tools for specific glycan biomarker discovery as they offer the potential to profile hundreds of array elements simultaneously, require minute amounts of reagents and are suitable for large scale sample analysis. Finally, these developing detection methodologies may be of great value in clinics for diagnostic/ prognostic purposes and for enabling patient-tailored treatments. 


\section{Acknowledgments}

This work was supported by Swiss National Foundation (320030-120543 and 310030-143619 to VHS; PBZHP3-133289 and -138752 to F.J.); Cancer Institute New South Wales (09/CRF/2-02 to V.H.S.); Royal Australian and New Zealand College of Obstetricians and Gynaecologists (to V.H.S.); William Maxwell Trust (to V.H.S.) and the Royal Hospital for Women Foundation (to V.H.S.).

\section{Conflict of Interest}

The authors declare no conflict of interest.

\section{References}

1. Hakomori, S. Tumor-associated carbohydrate antigens. Annu. Rev. Immunol. 1984, 2, 103-126.

2. Hakomori, S. Tumor-associated carbohydrate antigens defining tumor malignancy: Basis for development of anti-cancer vaccines. Adv. Exp. Med. Biol 2001, 491, 369-402.

3. Konska, G.; Guerry, M.; Caldefie-Chezet, F.; De Latour, M.; Guillot, J. Study of the expression of th antigen in different types of human breast cancer cells using vva-b4 lectin. Oncol. Rep. 2006, 15, 305-310.

4. Danussi, C.; Coslovi, A.; Campa, C.; Mucignat, M.T.; Spessotto, P.; Uggeri, F.; Paoletti, S.; Colombatti, A. A newly generated functional antibody identifies $t n$ antigen as a novel determinant in the cancer cell-lymphatic endothelium interaction. Glycobiology 2009, 19, 10561067.

5. Ghazarian, H.; Idoni, B.; Oppenheimer, S.B. A glycobiology review: Carbohydrates, lectins and implications in cancer therapeutics. Acta Histochem. 2011, 113, 236-247.

6. Hakomori, S. Aberrant glycosylation in tumors and tumor-associated carbohydrate antigens. $A d v$. Cancer Res. 1989, 52, 257-331.

7. Hakomori, S. Glycosylation defining cancer malignancy: New wine in an old bottle. Proc. Natl. Acad. Sci. USA 2002, 99, 10231-10233.

8. Powlesland, A.S.; Hitchen, P.G.; Parry, S.; Graham, S.A.; Barrio, M.M.; Elola, M.T.; Mordoh, J.; Dell, A.; Drickamer, K.; Taylor, M.E. Targeted glycoproteomic identification of cancer cell glycosylation. Glycobiology 2009, 19, 899-909.

9. Fuster, M.M.; Esko, J.D. The sweet and sour of cancer: Glycans as novel therapeutic targets. Nat. Rev. Cancer 2005, 5, 526-542.

10. Chandrasekaran, E.V.; Xue, J.; Neelamegham, S.; Matta, K.L. The pattern of glycosyl- and sulfotransferase activities in cancer cell lines: A predictor of individual cancer-associated distinct carbohydrate structures for the structural identification of signature glycans. Carbohydr. Res. 2006, 341, 983-994.

11. Hakomori, S. Possible functions of tumor-associated carbohydrate antigens. Curr. Opin. Immunol. 1991, 3, 646-653.

12. Muramatsu, T. Carbohydrate signals in metastasis and prognosis of human carcinomas. Glycobiology 1993, 3, 291-296. 
13. Brockhausen, I. Pathways of o-glycan biosynthesis in cancer cells. Biochim. Biophys. Acta 1999, 1473, 67-95.

14. Dennis, J.W.; Granovsky, M.; Warren, C.E. Glycoprotein glycosylation and cancer progression. Biochim. Biophys. Acta 1999, 1473, 21-34.

15. Chandrasekaran, E.V.; Xue, J.; Xia, J.; Chawda, R.; Piskorz, C.; Locke, R.D.; Neelamegham, S.; Matta, K.L. Analysis of the specificity of sialyltransferases toward mucin core 2, globo, and related structures. Identification of the sialylation sequence and the effects of sulfate, fucose, methyl, and fluoro substituents of the carbohydrate chain in the biosynthesis of selectin and siglec ligands, and novel sialylation by cloned alpha2,3(o)sialyltransferase. Biochemistry 2005, 44, 15619-15635.

16. Hebbar, M.; Krzewinski-Recchi, M.A.; Hornez, L.; Verdiere, A.; Harduin-Lepers, A.; Bonneterre, J.; Delannoy, P.; Peyrat, J.P. Prognostic value of tumoral sialyltransferase expression and circulating e-selectin concentrations in node-negative breast cancer patients. Int J. Biol. Markers 2003, 18, 116-122.

17. Recchi, M.A.; Hebbar, M.; Hornez, L.; Harduin-Lepers, A.; Peyrat, J.P.; Delannoy, P. Multiplex reverse transcription polymerase chain reaction assessment of sialyltransferase expression in human breast cancer. Cancer Res. 1998, 58, 4066-4070.

18. Ceroni, A.; Maass, K.; Geyer, H.; Geyer, R.; Dell, A.; Haslam, S.M. Glycoworkbench: A tool for the computer-assisted annotation of mass spectra of glycans. J. Proteome Res. 2008, 7, 1650 1659.

19. Dotan, I.; Fishman, S.; Dgani, Y.; Schwartz, M.; Karban, A.; Lerner, A.; Weishauss, O.; Spector, L.; Shtevi, A.; Altstock, R.T.; et al. Antibodies against laminaribioside and chitobioside are novel serologic markers in crohn's disease. Gastroenterology 2006, 131, $366-378$.

20. Hirche, T.O.; Stein, J.; Hirche, H.; Hausmann, J.; Wagner, T.O.; Behrens, F.; Schroder, O. Increased levels of anti-glycan antibodies in patients with cystic fibrosis. Eur. J. Med. Res. 2011, 16, 385-390.

21. Gyorgy, B.; Tothfalusi, L.; Nagy, G.; Pasztoi, M.; Geher, P.; Lorinc, Z.; Polgar, A.; Rojkovich, B.; Ujfalussy, I.; Poor, G.; et al. Natural autoantibodies reactive with glycosaminoglycans in rheumatoid arthritis. Arthritis Res. Ther. 2008, 10, R110.

22. A, V.D.; NS, V.D.V.; Smit, C.H.; Meevissen, M.H.; Hokke, C.H. Parasite glycans and antibodymediated immune responses in schistosoma infection. Parasitology 2012, 139, 1219-1230.

23. Blixt, O.; Bueti, D.; Burford, B.; Allen, D.; Julien, S.; Hollingsworth, M.; Gammerman, A.; Fentiman, I.; Taylor-Papadimitriou, J.; Burchell, J.M. Autoantibodies to aberrantly glycosylated mucl in early stage breast cancer are associated with a better prognosis. Breast Cancer Res. 2011, 13, R25.

24. Jacob, F.; Goldstein, D.R.; Bovin, N.V.; Pochechueva, T.; Spengler, M.; Caduff, R.; Fink, D.; Vuskovic, M.I.; Huflejt, M.E.; Heinzelmann-Schwarz, V. Serum antiglycan antibody detection of nonmucinous ovarian cancers by using a printed glycan array. Int. J. Cancer 2012, 130, 138-146.

25. Wandall, H.H.; Blixt, O.; Tarp, M.A.; Pedersen, J.W.; Bennett, E.P.; Mandel, U.; Ragupathi, G.; Livingston, P.O.; Hollingsworth, M.A.; Taylor-Papadimitriou, J.; et al. Cancer biomarkers 
defined by autoantibody signatures to aberrant o-glycopeptide epitopes. Cancer Res. 2010, 70, $1306-1313$.

26. Kurtenkov, O.; Klaamas, K.; Rittenhouse-Olson, K.; Vahter, L.; Sergejev, B.; Miljukhina, L.; Shljapnikova, L. Igg immune response to tumor-associated carbohydrate antigens (tf, tn, alphagal) in patients with breast cancer: Impact of neoadjuvant chemotherapy and relation to the survival. Exp. Oncol. 2005, 27, 136-140.

27. Smorodin, E.P.; Kurtenkov, O.A.; Sergeyev, B.L.; Pazynina, G.V.; Bovin, N.V. Specificity of human anti-carbohydrate igg antibodies as probed with polyacrylamide-based glycoconjugates. Glycoconj. J. 2004, 20, 83-89.

28. Springer, G.F. T and tn, general carcinoma autoantigens. Science 1984, 224, 1198-1206.

29. Brandlein, S.; Pohle, T.; Ruoff, N.; Wozniak, E.; Muller-Hermelink, H.K.; Vollmers, H.P. Natural igm antibodies and immunosurveillance mechanisms against epithelial cancer cells in humans. Cancer Res. 2003, 63, 7995-8005.

30. Slovin, S.F.; Keding, S.J.; Ragupathi, G. Carbohydrate vaccines as immunotherapy for cancer. Immunol. Cell. Biol. 2005, 83, 418-428.

31. Klaamas, K.; Kurtenkov, O.; Rittenhouse-Olson, K.; Brjalin, V.; Miljukhina, L.; Shljapnikova, L.; Engstrand, L. Expression of tumor-associated thomsen-friedenreich antigen ( $\mathrm{T} \mathrm{Ag}$ ) in helicobacter pylori and modulation of $\mathrm{t}$ ag specific immune response in infected individuals. Immunol. Invest. 2002, 31, 191-204.

32. Mosedale, D.E.; Chauhan, A.; Schofield, P.M.; Grainger, D.J. A pattern of anti-carbohydrate antibody responses present in patients with advanced atherosclerosis. J. Immunol. Methods 2006, 309, 182-191.

33. Obukhova, P.; Rieben, R.; Bovin, N. Normal human serum contains high levels of anti-gal alpha 1-4glcnac antibodies. Xenotransplantation 2007, 14, 627-635.

34. Smorodin, E.P.; Kurtenkov, O.A.; Sergeyev, B.L.; Kodar, K.E.; Chuzmarov, V.I.; Afanasyev, V.P. Postoperative change of anti-thomsen-friedenreich and tn igg level: The follow-up study of gastrointestinal cancer patients. World J. Gastroenterol. 2008, 14, 4352-4358.

35. Yeh, P.; Ezzelarab, M.; Bovin, N.; Hara, H.; Long, C.; Tomiyama, K.; Sun, F.; Ayares, D.; Awwad, M.; Cooper, D.K. Investigation of potential carbohydrate antigen targets for human and baboon antibodies. Xenotransplantation 2010, 17, 197-206.

36. Ferrante, M.; Henckaerts, L.; Joossens, M.; Pierik, M.; Joossens, S.; Dotan, N.; Norman, G.L.; Altstock, R.T.; Van Steen, K.; Rutgeerts, P.; et al. New serological markers in inflammatory bowel disease are associated with complicated disease behaviour. Gut 2007, 56, 1394-1403.

37. Rieder, F.; Schleder, S.; Wolf, A.; Dirmeier, A.; Strauch, U.; Obermeier, F.; Lopez, R.; Spector, L.; Fire, E.; Yarden, J.; et al. Association of the novel serologic anti-glycan antibodies antilaminarin and anti-chitin with complicated crohn's disease behavior. Inflamm. Bowel. Dis. 2010, $16,263-274$.

38. Rieder, F.; Schleder, S.; Wolf, A.; Dirmeier, A.; Strauch, U.; Obermeier, F.; Lopez, R.; Spector, L.; Fire, E.; Yarden, J.; et al. Serum anti-glycan antibodies predict complicated crohn's disease behavior: A cohort study. Inflamm. Bowel. Dis. 2010, 16, 1367-1375. 
39. Seow, C.H.; Stempak, J.M.; Xu, W.; Lan, H.; Griffiths, A.M.; Greenberg, G.R.; Steinhart, A.H.; Dotan, N.; Silverberg, M.S. Novel anti-glycan antibodies related to inflammatory bowel disease diagnosis and phenotype. Am. J. Gastroenterol. 2009, 104, 1426-1434.

40. Blixt, O.; Head, S.; Mondala, T.; Scanlan, C.; Huflejt, M.E.; Alvarez, R.; Bryan, M.C.; Fazio, F.; Calarese, D.; Stevens, J.; et al. Printed covalent glycan array for ligand profiling of diverse glycan binding proteins. Proc. Natl. Acad. Sci. USA 2004, 101, 17033-17038.

41. Schwarz, M.; Spector, L.; Gargir, A.; Shtevi, A.; Gortler, M.; Altstock, R.T.; Dukler, A.A.; Dotan, N. A new kind of carbohydrate array, its use for profiling antiglycan antibodies, and the discovery of a novel human cellulose-binding antibody. Glycobiology 2003, 13, 749-754.

42. Lee, M.R.; Shin, I. Facile preparation of carbohydrate microarrays by site-specific, covalent immobilization of unmodified carbohydrates on hydrazide-coated glass slides. Org. Lett. 2005, 7 , 4269-4272.

43. Papp, M.; Foldi, I.; Altorjay, I.; Palyu, E.; Udvardy, M.; Tumpek, J.; Sipka, S.; Korponay-Szabo, I.R.; Nemes, E.; Veres, G.; et al. Anti-microbial antibodies in celiac disease: Trick or treat? World J. Gastroenterol. 2009, 15, 3891-3900.

44. Ferrante, M.; Declerck, S.; Coopmans, T.; De Hertogh, G.; Van Assche, G.; Penninckx, F.; Rutgeerts, P.; Geboes, K.; D'Hoore, A.; Vermeire, S. Development of pouchitis following ileal pouch-anal anastomosis (ipaa) for ulcerative colitis: A role for serological markers and microbial pattern recognition receptor genes. J. Crohns. Colitis. 2008, 2, 142-151.

45. Sendid, B.; Dotan, N.; Nseir, S.; Savaux, C.; Vandewalle, P.; Standaert, A.; Zerimech, F.; Guery, B.P.; Dukler, A.; Colombel, J.F.; et al. Antibodies against glucan, chitin, and saccharomyces cerevisiae mannan as new biomarkers of candida albicans infection that complement tests based on c. Albicans mannan. Clin. Vaccine Immunol. 2008, 15, 1868-1877.

46. de Boer, A.R.; Hokke, C.H.; Deelder, A.M.; Wuhrer, M. Serum antibody screening by surface plasmon resonance using a natural glycan microarray. Glycoconj. J. 2008, 25, 75-84.

47. Pochechueva, T.; Chinarev, A.; Spengler, M.; Korchagina, E.; Heinzelmann-Schwarz, V.; Bovin, N.; Rieben, R. Multiplex suspension array for human anti-carbohydrate antibody profiling. Analyst 2010, 136, 560-569.

48. Pochechueva, T.; Jacob, F.; Goldstein, D.R.; Huflejt, M.E.; Chinarev, A.; Caduff, R.; Fink, D.; Hacker, N.; Bovin, N.V.; Heinzelmann-Schwarz, V. Comparison of printed glycan array, suspension array and elisa in the detection of human anti-glycan antibodies. Glycoconj. J. 2011, 28, 507-517.

49. Bovin, N.; Obukhova, P.; Shilova, N.; Rapoport, E.; Popova, I.; Navakouski, M.; Unverzagt, C.; Vuskovic, M.; Huflejt, M. Repertoire of human natural anti-glycan immunoglobulins. Do we have auto-antibodies? Biochim. Biophys. Acta 2012, 1820, 1373-1382.

50. Bovin, N.V.; Huflejt, M.E. Unlimited glycochip. Trends Glycosci. Glycotechnol. 2008, 20, 245258.

51. Huflejt, M.E.; Blixt, O.; Vuskovic, M.; Xu, H.; Shaw, L.E.; Reuben, J.M.; Kuerer, H.M. Glycan array identifies specific signatures of anti-glycan autoantibodies in sera of breast cancer patients: Diagnostic, prognostic and therapeutic opportunities. In the 28th Annual San Antonio Breast Cancer Symposium, 8-11 December 2005; p. 2008. 
52. Huflejt, M.E.; Vuskovic, M.; Vasiliu, D.; Xu, H.; Obukhova, P.; Shilova, N.; Tuzikov, A.; Galanina, O.; Arun, B.; Lu, K.; et al. Anti-carbohydrate antibodies of normal sera: Findings, surprises and challenges. Mol. Immunol. 2009, 46, 3037-3049.

53. Wang, C.C.; Huang, Y.L.; Ren, C.T.; Lin, C.W.; Hung, J.T.; Yu, J.C.; Yu, A.L.; Wu, C.Y.; Wong, C.H. Glycan microarray of globo $\mathrm{h}$ and related structures for quantitative analysis of breast cancer. Proc. Natl. Acad. Sci.USA 2008, 105, 11661-11666.

54. Huang, C.Y.; Thayer, D.A.; Chang, A.Y.; Best, M.D.; Hoffmann, J.; Head, S.; Wong, C.H. Carbohydrate microarray for profiling the antibodies interacting with globo $\mathrm{h}$ tumor antigen. Proc. Natl. Acad. Sci. USA 2006, 103, 15-20.

55. Dotan, N.; Altstock, R.T.; Schwarz, M.; Dukler, A. Anti-glycan antibodies as biomarkers for diagnosis and prognosis. Lupus 2006, 15, 442-450.

56. Freedman, M.S.; Laks, J.; Dotan, N.; Altstock, R.T.; Dukler, A.; Sindic, C.J. Anti-alpha-glucosebased glycan igm antibodies predict relapse activity in multiple sclerosis after the first neurological event. Mult. Scler. 2009, 15, 422-430.

57. Padler-Karavani, V.; Hurtado-Ziola, N.; Pu, M.; Yu, H.; Huang, S.; Muthana, S.; Chokhawala, H.A.; Cao, H.; Secrest, P.; Friedmann-Morvinski, D.; et al. Human xeno-autoantibodies against a non-human sialic acid serve as novel serum biomarkers and immunotherapeutics in cancer. Cancer Res. 2011.

58. Oyelaran, O.; Gildersleeve, J.C. Application of carbohydrate array technology to antigen discovery and vaccine development. Expert Rev. Vaccines 2007, 6, 957-969.

59. Oyelaran, O.; Gildersleeve, J.C. Evaluation of human antibody responses to keyhole limpet hemocyanin on a carbohydrate microarray. Proteomics Clin. Appl. 2010, 4, 285-294.

60. Oyelaran, O.; Gildersleeve, J.C. Glycan arrays: Recent advances and future challenges. Curr. Opin. Chem. Biol. 2009, 13, 406-413.

61. Oyelaran, O.; Li, Q.; Farnsworth, D.; Gildersleeve, J.C. Microarrays with varying carbohydrate density reveal distinct subpopulations of serum antibodies. J. Proteome Res. 2009, 8, 3529-3538.

62. Oyelaran, O.; McShane, L.M.; Dodd, L.; Gildersleeve, J.C. Profiling human serum antibodies with a carbohydrate antigen microarray. J. Proteome Res. 2009, 8, 4301-4310.

63. Pedersen, J.W.; Blixt, O.; Bennett, E.P.; Tarp, M.A.; Dar, I.; Mandel, U.; Poulsen, S.S.; Pedersen, A.E.; Rasmussen, S.; Jess, P.; et al. Seromic profiling of colorectal cancer patients with novel glycopeptide microarray. Int. J. Cancer 2011, 128, 1860-1871.

64. Tarp, M.A.; Sorensen, A.L.; Mandel, U.; Paulsen, H.; Burchell, J.; Taylor-Papadimitriou, J.; Clausen, H. Identification of a novel cancer-specific immunodominant glycopeptide epitope in the muc1 tandem repeat. Glycobiology 2007, 17, 197-209.

65. Gupta, G.; Surolia, A.; Sampathkumar, S.G. Lectin microarrays for glycomic analysis. OMICS 2010, 14, 419-436.

66. Krishhan, V.V.; Khan, I.H.; Luciw, P.A. Multiplexed microbead immunoassays by flow cytometry for molecular profiling: Basic concepts and proteomics applications. Crit. Rev. Biotechnol. 2009, 29, 29-43.

67. Pochechueva, T.; Chinarev, A.; Spengler, M.; Korchagina, E.; Heinzelmann-Schwarz, V.; Bovin, N.; Rieben, R. Multiplex suspension array for human anti-carbohydrate antibody profiling. Analyst 2011, 136, 560-569. 
68. Chinarev, A.A.; Galanina, O.E.; Bovin, N.V. Biotinylated multivalent glycoconjugates for surface coating. Methods Mol. Biol. 2010, 600, 67-78.

69. Nolan, J.P.; Sklar, L.A. Suspension array technology: Evolution of the flat-array paradigm. Trends Biotechnol. 2002, 20, 9-12.

70. Tyagi, A.; Wang, X.; Deng, L.; Ramstrom, O.; Yan, M. Photogenerated carbohydrate microarrays to study carbohydrate-protein interactions using surface plasmon resonance imaging. Biosens. Bioelectron. 2010, 26, 344-350.

71. Moreau, R.; Dausset, J.; Bernard, J.; Moullec, J. Acquired hemolytic anemia with polyagglutinability of erythrocytes by a new factor present in normal blood. Bull. Mem. Soc. Med. Hop. Paris 1957, 73, 569-587.

72. Cao, Y.; Stosiek, P.; Springer, G.F.; Karsten, U. Thomsen-friedenreich-related carbohydrate antigens in normal adult human tissues: A systematic and comparative study. Histochem Cell. Biol. 1996, 106, 197-207.

73. Howard, D.R.; Taylor, C.R. An antitumor antibody in normal human serum: Reaction of anti-t with breast carcinoma cells. Oncology 1980, 37, 142-148.

74. Stein, R.; Chen, S.; Grossman, W.; Goldenberg, D.M. Human lung carcinoma monoclonal antibody specific for the thomsen-friedenreich antigen. Cancer Res. 1989, 49, 32-37.

75. Wang, B.L.; Springer, G.F.; Carlstedt, S.C. Quantitative computerized image analysis of tn and $\mathrm{t}$ (thomsen-friedenreich) epitopes in prognostication of human breast carcinoma. J. Histochem. Cytochem. 1997, 45, 1393-1400.

76. Yuan, M.; Itzkowitz, S.H.; Boland, C.R.; Kim, Y.D.; Tomita, J.T.; Palekar, A.; Bennington, J.L.; Trump, B.F.; Kim, Y.S. Comparison of t-antigen expression in normal, premalignant, and malignant human colonic tissue using lectin and antibody immunohistochemistry. Cancer Res. 1986, 46, 4841-4847.

77. Korourian, S.; Siegel, E.; Kieber-Emmons, T.; Monzavi-Karbassi, B. Expression analysis of carbohydrate antigens in ductal carcinoma in situ of the breast by lectin histochemistry. BMC Cancer 2008, 8, 136.

78. Inoue, M.; Ogawa, H.; Nakanishi, K.; Tanizawa, O.; Karino, K.; Endo, J. Clinical value of sialyl th antigen in patients with gynecologic tumors. Obstet. Gynecol. 1990, 75, 1032-1036.

79. Numa, F.; Tsunaga, N.; Michioka, T.; Nawata, S.; Ogata, H.; Kato, H. Tissue expression of sialyl tn antigen in gynecologic tumors. J. Obstet. Gynaecol. (Tokyo 1995) 1995, 21, 385-389.

80. van Vliet, S.J.; Saeland, E.; van Kooyk, Y. Sweet preferences of mgl: Carbohydrate specificity and function. Trends Immunol. 2008, 29, 83-90.

81. Saeland, E.; van Vliet, S.J.; Backstrom, M.; van den Berg, V.C.; Geijtenbeek, T.B.; Meijer, G.A.; van Kooyk, Y. The c-type lectin mgl expressed by dendritic cells detects glycan changes on muc 1 in colon carcinoma. Cancer Immunol. Immunother. 2007, 56, 1225-1236.

82. Ju, T.; Aryal, R.P.; Stowell, C.J.; Cummings, R.D. Regulation of protein o-glycosylation by the endoplasmic reticulum-localized molecular chaperone cosmc. J. Cell. Biol. 2008, 182, 531-542.

83. Wang, Y.; Ju, T.; Ding, X.; Xia, B.; Wang, W.; Xia, L.; He, M.; Cummings, R.D. Cosmc is an essential chaperone for correct protein o-glycosylation. Proc. Natl. Acad. Sci. USA 2010, 107, 9228-9233. 
84. Springer, G.F.; Desai, P.R.; Tegtmeyer, H.; Spencer, B.D.; Scanlon, E.F. Pancarcinoma t/tn antigen detects human carcinoma long before biopsy does and its vaccine prevents breast carcinoma recurrence. Ann. N. Y. Acad. Sci. 1993, 690, 355-357.

85. Buskas, T.; Ingale, S.; Boons, G.J. Glycopeptides as versatile tools for glycobiology. Glycobiology 2006, 16, 113R-136R.

86. Slovin, S.F.; Ragupathi, G.; Musselli, C.; Olkiewicz, K.; Verbel, D.; Kuduk, S.D.; Schwarz, J.B.; Sames, D.; Danishefsky, S.; Livingston, P.O.; et al. Fully synthetic carbohydrate-based vaccines in biochemically relapsed prostate cancer: Clinical trial results with alpha-n-acetylgalactosamineo-serine/threonine conjugate vaccine. J. Clin. Oncol. 2003, 21, 4292-4298.

87. Kaiser, A.; Gaidzik, N.; Westerlind, U.; Kowalczyk, D.; Hobel, A.; Schmitt, E.; Kunz, H. A synthetic vaccine consisting of a tumor-associated sialyl-t(n)-muc1 tandem-repeat glycopeptide and tetanus toxoid: Induction of a strong and highly selective immune response. Angew. Chem. Int. Ed. Engl. 2009, 48, 7551-7555.

88. Napoletano, C.; Rughetti, A.; Agervig Tarp, M.P.; Coleman, J.; Bennett, E.P.; Picco, G.; Sale, P.; Denda-Nagai, K.; Irimura, T.; Mandel, U.; et al. Tumor-associated tn-muc1 glycoform is internalized through the macrophage galactose-type c-type lectin and delivered to the hla class $i$ and ii compartments in dendritic cells. Cancer Res. 2007, 67, 8358-8367.

89. Ragupathi, G.; Cereb, N.; Yang, S.Y. The relative distribution of b35 alleles and their ief isotypes in a hla-b35-positive population. Tissue Antigens 1995, 46, 24-31.

90. Sabbatini, P.J.; Ragupathi, G.; Hood, C.; Aghajanian, C.A.; Juretzka, M.; Iasonos, A.; Hensley, M.L.; Spassova, M.K.; Ouerfelli, O.; Spriggs, D.R.; et al. Pilot study of a heptavalent vaccinekeyhole limpet hemocyanin conjugate plus qs21 in patients with epithelial ovarian, fallopian tube, or peritoneal cancer. Clin. Cancer Res. 2007, 13, 4170-4177.

91. Blixt, O.; Lavrova, O.I.; Mazurov, D.V.; Clo, E.; Kracun, S.K.; Bovin, N.V.; Filatov, A.V. Analysis of th antigenicity with a panel of new igm and igg1 monoclonal antibodies raised against leukemic cells. Glycobiology 2012, 22, 529-542.

92. Kjeldsen, T.; Clausen, H.; Hirohashi, S.; Ogawa, T.; Iijima, H.; Hakomori, S. Preparation and characterization of monoclonal antibodies directed to the tumor-associated o-linked sialosyl-2---6 alpha-n-acetylgalactosaminyl (sialosyl-tn) epitope. Cancer Res. 1988, 48, 2214-2220.

93. Sewell, R.; Backstrom, M.; Dalziel, M.; Gschmeissner, S.; Karlsson, H.; Noll, T.; Gatgens, J.; Clausen, H.; Hansson, G.C.; Burchell, J.; et al. The st6galnac-i sialyltransferase localizes throughout the golgi and is responsible for the synthesis of the tumor-associated sialyl-tn oglycan in human breast cancer. J. Biol Chem. 2006, 281, 3586-3594.

94. Krzewinski-Recchi, M.-A.; Julien, S.; Juliant, S.; Teintenier-Lelievre, M.; Samyn-Petit, B.; Montiel, M.-D.; Mir, A.-M.; Cerutti, M.; Harduin-Lepers, A.; Delannoy, P. Identification and functional expression of a second human beta-galactoside alpha2,6-sialyltransferase, st6gal ii. Eur. J. Biochem. 2003, 270, 950-961.

95. Ghazizadeh, M.; Oguro, T.; Sasaki, Y.; Aihara, K.; Araki, T.; Springer, G.F. Immunohistochemical and ultrastructural localization of $\mathrm{t}$ antigen in ovarian tumors. Am. J. Clin. Pathol. 1990, 93, 315-321. 
96. Kinney, A.Y.; Sahin, A.; Vernon, S.W.; Frankowski, R.F.; Annegers, J.F.; Hortobagyi, G.N.; Buzdar, A.U.; Frye, D.K.; Dhingra, K. The prognostic significance of sialyl-tn antigen in women treated with breast carcinoma treated with adjuvant chemotherapy. Cancer 1997, 80, 2240-2249.

97. Leivonen, M.; Nordling, S.; Lundin, J.; von Boguslawski, K.; Haglund, C. Stn and prognosis in breast cancer. Oncology 2001, 61, 299.

98. Miles, D.W.; Happerfield, L.C.; Smith, P.; Gillibrand, R.; Bobrow, L.G.; Gregory, W.M.; Rubens, R.D. Expression of sialyl-tn predicts the effect of adjuvant chemotherapy in nodepositive breast cancer. Br. J. Cancer 1994, 70, 1272-1275.

99. Soares, R.; Marinho, A.; Schmitt, F. Expression of sialyl-tn in breast cancer. Correlation with prognostic parameters. Pathol. Res. Pract. 1996, 192, 1181-1186.

100. Kobayashi, H.; Terao, T.; Kawashima, Y. Serum sialyl th as an independent predictor of poor prognosis in patients with epithelial ovarian cancer. J. Clin. Oncol. 1992, 10, 95-101.

101. Davidson, B.; Berner, A.; Nesland, J.M.; Risberg, B.; Kristensen, G.B.; Trope, C.G.; Bryne, M. Carbohydrate antigen expression in primary tumors, metastatic lesions, and serous effusions from patients diagnosed with epithelial ovarian carcinoma: Evidence of up-regulated th and sialyl tn antigen expression in effusions. Hum. Pathol. 2000, 31, 1081-1087.

102. Davidson, B.; Gotlieb, W.H.; Ben-Baruch, G.; Kopolovic, J.; Goldberg, I.; Nesland, J.M.; Berner, A.; Bjamer, A.; Bryne, M. Expression of carbohydrate antigens in advanced-stage ovarian carcinomas and their metastases-a clinicopathologic study. Gynecol. Oncol. 2000, 77, 35-43.

103. Ikehara, Y.; Kojima, N.; Kurosawa, N.; Kudo, T.; Kono, M.; Nishihara, S.; Issiki, S.; Morozumi, K.; Itzkowitz, S.; Tsuda, T.; et al. Cloning and expression of a human gene encoding an nacetylgalactosamine-alpha2,6-sialyltransferase (st6galnac i): A candidate for synthesis of cancerassociated sialyl-tn antigens. Glycobiology 1999, 9, 1213-1224.

104. Vazquez-Martin, C.; Cuevas, E.; Gil-Martin, E.; Fernandez-Briera, A. Correlation analysis between tumor-associated antigen sialyl-tn expression and st6galnac i activity in human colon adenocarcinoma. Oncology 2004, 67, 159-165.

105. Ogata, S.; Ho, I.; Chen, A.; Dubois, D.; Maklansky, J.; Singhal, A.; Hakomori, S.; Itzkowitz, S.H. Tumor-associated sialylated antigens are constitutively expressed in normal human colonic mucosa. Cancer Res. 1995, 55, 1869-1874.

106. Van Elssen, C.H.; Frings, P.W.; Bot, F.J.; Van de Vijver, K.K.; Huls, M.B.; Meek, B.; Hupperets, P.; Germeraad, W.T.; Bos, G.M. Expression of aberrantly glycosylated mucin-1 in ovarian cancer. Histopathology 2010, 57, 597-606.

107. Singh, R.; Campbell, B.J.; Yu, L.G.; Fernig, D.G.; Milton, J.D.; Goodlad, R.A.; FitzGerald, A.J.; Rhodes, J.M. Cell surface-expressed thomsen-friedenreich antigen in colon cancer is predominantly carried on high molecular weight splice variants of cd44. Glycobiology 2001, 11, 587-592.

108. Akita, K.; Yoshida, S.; Ikehara, Y.; Shirakawa, S.; Toda, M.; Inoue, M.; Kitawaki, J.; Nakanishi, H.; Narimatsu, H.; Nakada, H. Different levels of sialyl-tn antigen expressed on muc16 in patients with endometriosis and ovarian cancer. Int. J. Gynecol. Cancer 2012, 22, 531-538.

109. Julien, S.; Adriaenssens, E.; Ottenberg, K.; Furlan, A.; Courtand, G.; Vercoutter-Edouart, A.S.; Hanisch, F.G.; Delannoy, P.; Le Bourhis, X. St6galnac i expression in mda-mb-231 breast cancer 
cells greatly modifies their o-glycosylation pattern and enhances their tumourigenicity. Glycobiology 2006, 16, 54-64.

110. Julien, S.; Lagadec, C.; Krzewinski-Recchi, M.A.; Courtand, G.; Le Bourhis, X.; Delannoy, P. Stable expression of sialyl-tn antigen in t47-d cells induces a decrease of cell adhesion and an increase of cell migration. Breast Cancer Res. Treat. 2005, 90, 77-84.

111. Aruffo, A.; Stamenkovic, I.; Melnick, M.; Underhill, C.B.; Seed, B. Cd44 is the principal cell surface receptor for hyaluronate. Cell 1990, 61, 1303-1313.

112. Gunthert, U.; Hofmann, M.; Rudy, W.; Reber, S.; Zoller, M.; Haussmann, I.; Matzku, S.; Wenzel, A.; Ponta, H.; Herrlich, P. A new variant of glycoprotein cd44 confers metastatic potential to rat carcinoma cells. Cell 1991, 65, 13-24.

113. $\mathrm{Yu}, \mathrm{L} . \mathrm{G}$. The oncofetal thomsen-friedenreich carbohydrate antigen in cancer progression. Glycoconj. J. 2007, 24, 411-420.

114. Springer, G.F.; Desai, P.R.; Banatwala, I. Blood group mn antigens and precursors in normal and malignant human breast glandular tissue. J. Natl. Cancer Inst. 1975, 54, 335-339.

115. Springer, G.F.; Desai, P.R.; Murthy, M.S.; Scanlon, E.F. Human carcinoma-associated precursor antigens of the nm blood group system. J. Surg Oncol 1979, 11, 95-106.

116. Springer, G.F. Immunoreactive $\mathrm{t}$ and $\mathrm{tn}$ epitopes in cancer diagnosis, prognosis, and immunotherapy. J. Mol. Med. (Berl) 1997, 75, 594-602.

117. Barry, J.D.; Koch, T.J.; Cohen, C.; Brigati, D.J.; Sharkey, F.E. Correlation of immunohistochemical markers with patient prognosis in breast carcinoma: A quantitative study. Am. J. Clin. Pathol. 1984, 82, 582-585.

118. Wolf, M.F.; Ludwig, A.; Fritz, P.; Schumacher, K. Increased expression of thomsen-friedenreich antigens during tumor progression in breast cancer patients. Tumour Biol. 1988, 9, 190-194.

119. Schindlbeck, C.; Jeschke, U.; Schulze, S.; Karsten, U.; Janni, W.; Rack, B.; Krajewski, S.; Sommer, H.; Friese, K. Prognostic impact of thomsen-friedenreich tumor antigen and disseminated tumor cells in the bone marrow of breast cancer patients. Breast Cancer Res. Treat. 2007, 101, 17-25.

120. Engelstaedter, V.; Fluegel, B.; Kunze, S.; Mayr, D.; Friese, K.; Jeschke, U.; Bergauer, F. Expression of the carbohydrate tumour marker sialyl lewis a, sialyl lewis $\mathrm{x}$, lewis $\mathrm{y}$ and thomsenfriedenreich antigen in normal squamous epithelium of the uterine cervix, cervical dysplasia and cervical cancer. Histol. Histopathol. 2012, 27, 507-514.

121. Cazet, A.; Julien, S.; Bobowski, M.; Burchell, J.; Delannoy, P. Tumour-associated carbohydrate antigens in breast cancer. Breast Cancer Res. 2010, 12, 204.

122. Hanisch, F.G.; Baldus, S.E. The thomsen-friedenreich (tf) antigen: A critical review on the structural, biosynthetic and histochemical aspects of a pancarcinoma-associated antigen. Histol. Histopathol. 1997, 12, 263-281.

123. Butschak, G.; Karsten, U. Isolation and characterization of thomsen-friedenreich-specific antibodies from human serum. Tumour Biol. 2002, 23, 113-122.

124. Bychkov, V.; Dolan, J.R.; Reddy, V.B. Lectin binding to common epithelial tumors of the ovaries. Gynecol. Obstet. Invest. 1991, 31, 166-171.

125. Sasano, H.; Saito, Y.; Nagura, H.; Kudo, R.; Rojas, M.; Silverberg, S.G. Lectin histochemistry in mucinous and serous ovarian neoplasms. Int. J. Gynecol. Pathol. 1991, 10, 252-259. 
126. Glinsky, V.V.; Glinsky, G.V.; Glinskii, O.V.; Huxley, V.H.; Turk, J.R.; Mossine, V.V.; Deutscher, S.L.; Pienta, K.J.; Quinn, T.P. Intravascular metastatic cancer cell homotypic aggregation at the sites of primary attachment to the endothelium. Cancer Res. 2003, 63, 38053811.

127. Khaldoyanidi, S.K.; Glinsky, V.V.; Sikora, L.; Glinskii, A.B.; Mossine, V.V.; Quinn, T.P.; Glinsky, G.V.; Sriramarao, P. Mda-mb-435 human breast carcinoma cell homo- and heterotypic adhesion under flow conditions is mediated in part by thomsen-friedenreich antigen-galectin-3 interactions. J. Biol. Chem. 2003, 278, 4127-4134.

128. Bian, C.F.; Zhang, Y.; Sun, H.; Li, D.F.; Wang, D.C. Structural basis for distinct binding properties of the human galectins to thomsen-friedenreich antigen. PLoS One 2011, 6, e25007.

129. Almogren, A.; Abdullah, J.; Ghapure, K.; Ferguson, K.; Glinsky, V.V.; Rittenhouse-Olson, K. Anti-thomsen-friedenreich-ag (anti-tf-ag) potential for cancer therapy. Front. Biosci. (Schol Ed.) 2012, 4, 840-863.

130. MacLean, G.D.; Bowen-Yacyshyn, M.B.; Samuel, J.; Meikle, A.; Stuart, G.; Nation, J.; Poppema, S.; Jerry, M.; Koganty, R.; Wong, T.; et al. Active immunization of human ovarian cancer patients against a common carcinoma (thomsen-friedenreich) determinant using a synthetic carbohydrate antigen. J. Immunother. (1991) 1992, 11, 292-305.

131. Narita, T.; Funahashi, H.; Satoh, Y.; Watanabe, T.; Sakamoto, J.; Takagi, H. Association of expression of blood group-related carbohydrate antigens with prognosis in breast cancer. Cancer 1993, 71, 3044-3053.

132. Ura, Y.; Dion, A.S.; Williams, C.J.; Olsen, B.D.; Redfield, E.S.; Ishida, M.; Herlyn, M.; Major, P.P. Quantitative dot blot analyses of blood-group-related antigens in paired normal and malignant human breast tissues. Int. J. Cancer 1992, 50, 57-63.

133. Idikio, H.A.; Manickavel, V. Lewis blood group antigens (a and b) in human breast tissues. Loss of lewis-b in breast cancer cells and correlation with tumor grade. Cancer 1991, 68, 1303-1308.

134. Idikio, H.A.; Manickavel, V. A, B, H, and lewis-a and lewis-b blood group antigens in human breast cancer: Correlation with steroid hormone receptor and disease status. J. Cancer Res. Clin. Oncol. 1993, 119, 486-492.

135. Abd Hamid, U.M.; Royle, L.; Saldova, R.; Radcliffe, C.M.; Harvey, D.J.; Storr, S.J.; Pardo, M.; Antrobus, R.; Chapman, C.J.; Zitzmann, N.; et al. A strategy to reveal potential glycan markers from serum glycoproteins associated with breast cancer progression. Glycobiology 2008, 18, 1105-1118.

136. Matsuura, N.; Narita, T.; Mitsuoka, C.; Kimura, N.; Kannagi, R.; Imai, T.; Funahashi, H.; Takagi, H. Increased level of circulating adhesion molecules in the sera of breast cancer patients with distant metastases. Jpn. J. Clin. Oncol. 1997, 27, 135-139.

137. Ordonez, N.G.; Freedman, R.S.; Herlyn, M. Lewis and related tumor-associated determinants on ovarian carcinoma. Gynecol. Oncol. 1987, 26, 1-10.

138. Takehara, K.; Kubushiro, K.; Kiguchi, K.; Ishiwata, I.; Tsukazaki, K.; Nozawa, S.; Iwamori, M. Expression of glycolipids bearing lewis phenotypes in tissues and cultured cells of human gynecological cancers. Jpn J. Cancer Res. 2002, 93, 1129-1137.

139. Dabelsteen, E. Cell surface carbohydrates as prognostic markers in human carcinomas. J. Pathol 1996, 179, 358-369. 
140. Muller, S.; Hanisch, F.-G. Recombinant mucl probe authentically reflects cell-specific oglycosylation profiles of endogenous breast cancer mucin. High density and prevalent core 2based glycosylation. J. Biol. Chem. 2002, 277, 26103-26112.

141. Nakagoe, T.; Fukushima, K.; Itoyanagi, N.; Ikuta, Y.; Oka, T.; Nagayasu, T.; Ayabe, H.; Hara, S.; Ishikawa, H.; Minami, H. Expression of abh/lewis-related antigens as prognostic factors in patients with breast cancer. J. Cancer Res. Clin. Oncol. 2002, 128, 257-264.

142. Kurebayashi, J.; Nomura, T.; Hirono, M.; Okubo, S.; Udagawa, K.; Shiiki, S.; Ikeda, M.; Nakashima, K.; Tanaka, K.; Sonoo, H. Combined measurement of serum sialyl lewis x with serum ca15-3 in breast cancer patients. Jpn. J. Clin. Oncol. 2006, 36, 150-153.

143. Sozzani, P.; Arisio, R.; Porpiglia, M.; Benedetto, C. Is sialyl lewis $\mathrm{x}$ antigen expression a prognostic factor in patients with breast cancer? Int J. Surg. Pathol. 2008, 16, 365-374.

144. Saldova, R.; Royle, L.; Radcliffe, C.M.; Abd Hamid, U.M.; Evans, R.; Arnold, J.N.; Banks, R.E.; Hutson, R.; Harvey, D.J.; Antrobus, R.; et al. Ovarian cancer is associated with changes in glycosylation in both acute-phase proteins and igg. Glycobiology 2007, 17, 1344-1356.

145. Berg, E.L.; Robinson, M.K.; Mansson, O.; Butcher, E.C.; Magnani, J.L. A carbohydrate domain common to both sialyl le(a) and sialyl le(x) is recognized by the endothelial cell leukocyte adhesion molecule elam-1. J. Biol. Chem. 1991, 266, 14869-14872.

146. Narita, T.; Kawasaki-Kimura, N.; Matsuura, N.; Funahashi, H.; Kannagi, R. Adhesion of human breast cancer cells to vascular endothelium mediated by sialyl lewis \&supx; /e-selectin. Breast Cancer 1996, 3, 19-23.

147. Ohyama, C.; Tsuboi, S.; Fukuda, M. Dual roles of sialyl lewis x oligosaccharides in tumor metastasis and rejection by natural killer cells. EMBO J. 1999, 18, 1516-1525.

148. Phillips, M.L.; Nudelman, E.; Gaeta, F.C.; Perez, M.; Singhal, A.K.; Hakomori, S.; Paulson, J.C. Elam-1 mediates cell adhesion by recognition of a carbohydrate ligand, sialyl-lex. Science 1990, 250, 1130-1132.

149. Takada, A.; Ohmori, K.; Takahashi, N.; Tsuyuoka, K.; Yago, A.; Zenita, K.; Hasegawa, A.; Kannagi, R. Adhesion of human cancer cells to vascular endothelium mediated by a carbohydrate antigen, sialyl lewis a. Biochem. Biophys. Res. Commun. 1991, 179, 354-361.

150. Takada, A.; Ohmori, K.; Yoneda, T.; Tsuyuoka, K.; Hasegawa, A.; Kiso, M.; Kannagi, R. Contribution of carbohydrate antigens sialyl lewis a and sialyl lewis $\mathrm{x}$ to adhesion of human cancer cells to vascular endothelium. Cancer Res. 1993, 53, 354-361.

151. Matsuura, N.; Narita, T.; Mitsuoka, C.; Kimura, N.; Kannagi, R.; Imai, T.; Funahashi, H.; Takagi, H. Increased concentration of soluble e-selectin in the sera of breast cancer patients. Anticancer Res. 1997, 17, 1367-1372.

152. Renkonen, R.; Mattila, P.; Majuri, M.L.; Rabina, J.; Toppila, S.; Renkonen, J.; Hirvas, L.; Niittymaki, J.; Turunen, J.P.; Renkonen, O.; et al. In vitro experimental studies of sialyl lewis $\mathrm{x}$ and sialyl lewis a on endothelial and carcinoma cells: Crucial glycans on selectin ligands. Glycoconj. J. 1997, 14, 593-600.

153. Julien, S.; Ivetic, A.; Grigoriadis, A.; QiZe, D.; Burford, B.; Sproviero, D.; Picco, G.; Gillett, C.; Papp, S.L.; Schaffer, L.; et al. Selectin ligand sialyl-lewis $\mathrm{x}$ antigen drives metastasis of hormone-dependent breast cancers. Cancer Res. 2011, 71, 7683-7693. 
154. Somers, W.S.; Tang, J.; Shaw, G.D.; Camphausen, R.T. Insights into the molecular basis of leukocyte tethering and rolling revealed by structures of $\mathrm{p}$ - and e-selectin bound to sle(x) and psg1-1. Cell 2000, 103, 467-479.

155. Sperandio, M.; Gleissner, C.A.; Ley, K. Glycosylation in immune cell trafficking. Immunol Rev. 2009, 230, 97-113.

156. Yago, T.; Fu, J.; McDaniel, J.M.; Miner, J.J.; McEver, R.P.; Xia, L. Core 1-derived o-glycans are essential e-selectin ligands on neutrophils. Proc. Natl. Acad. Sci. USA 2010, 107, 9204-9209.

157. Hellstrom, I.; Garrigues, H.J.; Garrigues, U.; Hellstrom, K.E. Highly tumor-reactive, internalizing, mouse monoclonal antibodies to le(y)-related cell surface antigens. Cancer Res. 1990, 50, 2183-2190.

158. Madjd, Z.; Parsons, T.; Watson, N.F.; Spendlove, I.; Ellis, I.; Durrant, L.G. High expression of lewis $\mathrm{y} / \mathrm{b}$ antigens is associated with decreased survival in lymph node negative breast carcinomas. Breast Cancer Res. 2005, 7, R780-787.

159. Federici, M.F.; Kudryashov, V.; Saigo, P.E.; Finstad, C.L.; Lloyd, K.O. Selection of carbohydrate antigens in human epithelial ovarian cancers as targets for immunotherapy: Serous and mucinous tumors exhibit distinctive patterns of expression. Int. J. Cancer 1999, 81, 193198.

160. Iwamori, M.; Iwamori, Y.; Kubushiro, K.; Ishiwata, I.; Kiguchi, K. Characteristic expression of lewis-antigenic glycolipids in human ovarian carcinoma-derived cells with anticancer drugresistance. J. Biochem. 2007, 141, 309-317.

161. Wang, C.; Yan, L.; Wang, Y.; Lin, B.; Liu, S.; Li, Q.; Gao, L.; Zhang, S.; Iwamori, M. Overexpression of lewis(y) antigen protects ovarian cancer rmg-1 cells from carboplatin-induced apoptosis by the upregulation of topo-i and topo-ii beta. Anat. Rec. (Hoboken) 2011, 294, 961969.

162. Gao, L.; Yan, L.; Lin, B.; Gao, J.; Liang, X.; Wang, Y.; Liu, J.; Zhang, S.; Iwamori, M. Enhancive effects of lewis y antigen on cd44-mediated adhesion and spreading of human ovarian cancer cell line rmg-i. J. Exp. Clin. Cancer Res. 2011, 30, 15.

163. Fukushi, Y.; Kannagi, R.; Hakomori, S.; Shepard, T.; Kulander, B.G.; Singer, J.W. Location and distribution of difucoganglioside (vi3neuacv3iii3fuc2nlc6) in normal and tumor tissues defined by its monoclonal antibody fh6. Cancer Res. 1985, 45, 3711-3717.

164. Bos, P.D.; Zhang, X.H.F.; Nadal, C.; Shu, W.; Gomis, R.R.; Nguyen, D.X.; Minn, A.J.; van de Vijver, M.J.; Gerald, W.L.; Foekens, J.A.; et al. Genes that mediate breast cancer metastasis to the brain. Nature 2009, 459, 1005-1009.

165. Cazet, A.; Groux-Degroote, S.; Teylaert, B.; Kwon, K.-M.; Lehoux, S.; Slomianny, C.; Kim, C.H.; Le Bourhis, X.; Delannoy, P. Gd3 synthase overexpression enhances proliferation and migration of mda-mb-231 breast cancer cells. Biol. Chem. 2009, 390, 601-609.

166. Battula, V.L.; Shi, Y.; Evans, K.W.; Wang, R.Y.; Spaeth, E.L.; Jacamo, R.O.; Guerra, R.; Sahin, A.A.; Marini, F.C.; Hortobagyi, G.; et al. Ganglioside gd2 identifies breast cancer stem cells and promotes tumorigenesis. J. Clin. Invest. 2012, 122, 2066-2078.

167. Marquina, G.; Waki, H.; Fernandez, L.E.; Kon, K.; Carr, A.; Valiente, O.; Perez, R.; Ando, S. Gangliosides expressed in human breast cancer. Cancer Res. 1996, 56, 5165-5171. 
168. Oliva, J.P.; Valdes, Z.; Casaco, A.; Pimentel, G.; Gonzalez, J.; Alvarez, I.; Osorio, M.; Velazco, M.; Figueroa, M.; Ortiz, R.; et al. Clinical evidences of gm3 (neugc) ganglioside expression in human breast cancer using the $14 \mathrm{f7}$ monoclonal antibody labelled with $(99 \mathrm{~m}) \mathrm{tc}$. Breast Cancer Res. Treat. 2006, 96, 115-121.

169. Santin, A.D.; Ravindranath, M.H.; Bellone, S.; Muthugounder, S.; Palmieri, M.; O'Brien, T.J.; Roman, J.; Cannon, M.J.; Pecorelli, S. Increased levels of gangliosides in the plasma and ascitic fluid of patients with advanced ovarian cancer. BJOG 2004, 111, 613-618.

170. Webb, T.J.; Li, X.; Giuntoli, R.L.; Lopez, P.H.H.; Heuser, C.; Schnaar, R.L.; Tsuji, M.; Kurts, C.; Oelke, M.; Schneck, J.P. Molecular identification of $\mathrm{gd} 3$ as a suppressor of the innate immune response in ovarian cancer. Cancer Res. 2012, 72, 3744.

171. Bremer, E.G.; Levery, S.B.; Sonnino, S.; Ghidoni, R.; Canevari, S.; Kannagi, R.; Hakomori, S. Characterization of a glycosphingolipid antigen defined by the monoclonal antibody mbr1 expressed in normal and neoplastic epithelial cells of human mammary gland. J. Biol. Chem. 1984, 259, 14773-14777.

172. Perrone, F.; Menard, S.; Canevari, S.; Calabrese, M.; Boracchi, P.; Bufalino, R.; Testori, S.; Baldini, M.; Colnaghi, M.I. Prognostic significance of the cambr1 antigen on breast carcinoma: Relevance of the type of recognised glycoconjugate. Eur. J. Cancer 1993, 29A, 2113-2117.

173. Mariani-Costantini, R.; Colnaghi, M.I.; Leoni, F.; Menard, S.; Cerasoli, S.; Rilke, F. Immunohistochemical reactivity of a monoclonal antibody prepared against human breast carcinoma. Virchows Arch. A Pathol Anat Histopathol 1984, 402, 389-404.

174. Sharon, N. Lectins: Carbohydrate-specific reagents and biological recognition molecules. J. Biol. Chem. 2007, 282, 2753-2764.

175. Kyselova, Z.; Mechref, Y.; Kang, P.; Goetz, J.A.; Dobrolecki, L.E.; Sledge, G.W.; Schnaper, L.; Hickey, R.J.; Malkas, L.H.; Novotny, M.V. Breast cancer diagnosis and prognosis through quantitative measurements of serum glycan profiles. Clin. Chem. 2008, 54, 1166-1175.

(C) 2012 by the authors; licensee MDPI, Basel, Switzerland. This article is an open access article distributed under the terms and conditions of the Creative Commons Attribution license (http://creativecommons.org/licenses/by/3.0/). 